\title{
Particulate biogenic barium tracer of mesopelagic carbon remineralization in the Mediterranean Sea (PEACETIME project)
}

\author{
Stéphanie H. M. Jacquet, Christian Tamburini, Marc Garel, Aurélie Dufour, France Van Vambeke, \\ Frédéric A. C. Le Moigne, Nagib Bhairy, and Sophie Guasco \\ Aix Marseille Université, CNRS/INSU, Université de Toulon, IRD, Mediterranean Institute of Oceanography (MIO), \\ UM 110, 13288 Marseille, France
}

Correspondence: Stephanie H. M. Jacquet (stephanie.jacquet@mio.osupytheas.fr)

Received: 15 July 2020 - Discussion started: 23 September 2020

Revised: 6 September 2021 - Accepted: 29 September 2021 - Published: 16 November 2021

\begin{abstract}
We report on the sub-basin variability in particulate organic carbon (POC) remineralization in the western and central Mediterranean Sea in late spring during the PEACETIME (ProcEss studies at the Air-sEa Interface after dust deposition in the MEditerranean sea) cruise. POC remineralization rates were estimated using the excess biogenic particulate barium $\left(\mathrm{Ba}_{\mathrm{xs}}\right)$ inventories in the mesopelagic layers (100-1000 m depth) and compared with prokaryotic heterotrophic production (PHP). $\mathrm{Ba}_{\mathrm{xs}}$-based mesopelagic remineralization rates (MRs) ranged from $25 \pm 2$ to $306 \pm$ $70 \mathrm{mg} \mathrm{C} \mathrm{m}^{-2} \mathrm{~d}^{-1}$. MRs were larger in the Algero-Provençal (ALG) Basin than in the Tyrrhenian (TYR) and Ionian (ION) basins. Our $\mathrm{Ba}_{\mathrm{xs}}$ inventories and integrated PHP data also indicated that significant mesopelagic remineralization occurred down to $1000 \mathrm{~m}$ depth in the ALG Basin in contrast to the ION and TYR basins, where remineralization was mainly located above $500 \mathrm{~m}$ depth. We propose that the higher and deeper MRs in the ALG Basin were sustained by an additional particle export event driven by deep convection. The TYR Basin (in contrast to the ALG and ION basins) presented the impact of a previous dust event, as reflected by our particulate $\mathrm{Al}$ water column concentrations. The ION and TYR basins showed small-scale heterogeneity in remineralization processes, reflected by our $\mathrm{Ba}_{\mathrm{xs}}$ inventories and integrated PHP data at the Tyrr long-duration station. This heterogeneity was linked to the mosaic of blooming and non-blooming patches reported in this area during the cruise. In contrast to the western Mediterranean Sea (ALG Basin), the central Mediterranean Sea (ION and TYR basins) showed lower remineralization rates restricted to the
\end{abstract}

upper mesopelagic layer during the late spring PEACETIME cruise.

\section{Introduction}

In the ocean, the remineralization rate associated with sinking particles is a crucial variable for the air-sea $\mathrm{CO}_{2}$ balance (Kwon et al., 2009). Most of the sinking particulate organic carbon (POC) conversion (i.e. remineralization) into $\mathrm{CO}_{2}$ by heterotrophic organisms (i.e. respiration) occurs within the mesopelagic zone (100-1000 m) (Martin et al., 1987; Buesseler et al., 2007; Buesseler and Boyd, 2009). Thus, a quantitative representation of this process is crucial for future predictions of the ocean's role in the global $\mathrm{C}$ cycle (IPCC, 2014). Particulate biogenic barium $\left(\mathrm{Ba}_{\mathrm{xs}}\right)$ is a geochemical tracer of $\mathrm{POC}$ remineralization in the mesopelagic layer. $\mathrm{Ba}_{\mathrm{xs}}$ occurs in the form of barite $\left(\mathrm{BaSO}_{4}\right.$ crystals) in the dark ocean as a by-product of prokaryotic remineralization. In a global ocean undersaturated with respect to barite (Monnin and Cividini, 2006), $\mathrm{Ba}_{\mathrm{xs}}$ precipitates inside oversaturated biogenic micro-environments during POC degradation by heterotrophic prokaryotes, through sulfate and/or barium enrichment (Dehairs et al., 1980; Stroobant et al., 1991; Bertram and Cowen, 1997; Ganeshram et al., 2003). By applying a transfer function relating $\mathrm{Ba}_{\mathrm{xs}}$ to $\mathrm{O}_{2}$ consumption (Dehairs et al., 1997) $\mathrm{Ba}_{\mathrm{xs}}$ has been widely used since the 1990s as an estimator of mesopelagic POC remineralization rates in various sectors of the Southern Ocean, North Pacific and North Atlantic (Cardinal et al., 2001, 2005; Dehairs et 
al., 2008; Jacquet et al., 2008a, b, 2011, 2015; Planchon et al., 2013; Lemaitre et al., 2018). Jacquet et al. (2021) recently reported that such a transfer function could be applied in the Mediterranean Sea without restriction. The above-mentioned study complemented previous investigations that aimed at improving the use of $\mathrm{Ba}_{\mathrm{xs}}$ to estimate local POC remineralization processes in the Mediterranean Sea (Jacquet et al., 2016; Jullion et al., 2017). The Mediterranean Sea represents a unique case study, mainly due to unresolved issues related to the imbalance in the regional $\mathrm{C}$ budget, such as the coupling between surface biology and deeper remineralization, the timescales of their variability between basins, and discrepancies between mesopelagic trophic structure and respiration dynamics (Sternberg et al., 2007, 2008; Santinelli et al., 2010; Lopez-Sandoval et al., 2011; Luna et al., 2012; Tanhua et al., 2013b; Malanotte-Rissoli et al., 2014).

The present work is part of the PEACETIME (ProcEss studies at the Air-sEa Interface after dust deposition in the MEditerranean sea) project (http://peacetime-project.org/, last access: 7 April 2021), which aims to study the impact of atmospheric Saharan dust on Mediterranean biogeochemistry (Guieu et al., 2020a). Dust deposition is a major source of macro- and micronutrients and ballasted material to surface waters that likely impacts the biological carbon pump through organic matter production (i.e. primary production) and its subsequent export and remineralization in the water column (Pabortsava et al., 2017; Gazeau et al., 2021). Overall, the aims of the present contribution to the PEACETIME project were (1) to document particulate biogenic $\mathrm{Ba}_{\mathrm{xs}}$ in different ecoregions of the western and central parts of the Mediterranean Sea, as previous $\mathrm{Ba}_{\mathrm{xs}}$ data in the Mediterranean Sea are relatively scarce with limited vertical sampling resolution (Sanchez-Vidal et al., 2005) or restricted locations (Dehairs et al., 1987; Sternberg et al., 2007, 2008; van Beek et al., 2009); (2) to determine the relationship between $\mathrm{Ba}_{\mathrm{xs}}$ and environmental variability, including dust deposition; (3) to estimate $\mathrm{Ba}_{\mathrm{xs}}$-based $\mathrm{POC}$ remineralization rates (MRs) at mesopelagic depths using Dehairs' transfer function (Dehairs et al., 1997), which we recently validated for the Mediterranean Sea (Jacquet et al., 2021); and (4) to assess potential differences in the remineralization length scale of POC in the various ecoregions of the Mediterranean Sea.

\section{Material and methods}

\subsection{Study area}

The PEACETIME cruise (https://doi.org/10.17600/ 17000300) was conducted during late spring, from 10 May to 11 June 2017, in the western and central Mediterranean using the French research vessel (RV) Pourquoi pas? (Fig. 1a). The Mediterranean Sea is a semi-landlocked sea with limited but crucial exchange with the Atlantic Ocean, two deep overturning cells, one shallow circulation, and a complex upper-layer circulation with several permanent and quasi-permanent eddies.

The hydrography during the PEACETIME cruise was characterized by three layers: surface, intermediate and deep waters, typical for the Mediterranean (Tamburini et al., 2013; Tanhua et al., 2013a; Hainbucher et al., 2014, MalanotteRizzoli et al., 2014). Briefly, the main water masses are (see potential temperature-salinity diagram in Fig. 1b) as follows: (1) from west to east, Atlantic Surface Water (SW) is gradually replaced by Ionian Surface Water (ISW) and Levantine Surface Water (LSW); (2) Winter Intermediate Water (WIW); (3) Levantine Intermediate Water (LIW), which is present at intermediate depths (from 200 to $800 \mathrm{~m}$ ) and is characterized by a local maximum of salinity and a local minimum of dissolved oxygen concentration; and (4) Mediterranean Deep Water (MDW).

Three main ecoregions (Reygondeau et al., 2017; Ayata et al., 2018) were crossed during the cruise: the AlgeroProvençal Basin (later referred to as ALG), the Tyrrhenian Basin (TYR) and the Ionian Basin (ION) (Fig. 1a). These basins displayed the typical eastward oligotrophic gradient reported in previous studies (Moutin and Raimbault, 2002; Durrieu de Madron et al., 2011; Pujo-Pay et al., 2011; Tanhua et al., 2013a; Reygondeau et al., 2017; Guieu et al., 2020a). However, this trend was not homogeneous - for instance, in the Ionian Sea (a crossroad for waters with contrasting biological histories) where a mosaic of blooming and nonblooming areas co-occurred in spring (Berline et al., 2021). A diatom-dominated deep chlorophyll maximum that coincided with a maximum in biomass and primary production (PP) was well developed and observed along the entire cruise track (Marañón et al., 2021). PP is described in detail in Van Wambeke et al. (2020). Furthermore, important dust deposition affected the TYR Basin a few days before our arrival at station nos. Tyrr and 5, whereas in the ALG Basin, dust deposition occurred few hours before our sampling at Fast station (Bressac et al., 2021). POC downward fluxes measured at $200 \mathrm{~m}$ depth were similar at the three long-duration stations (Fast, Tyrr and Ion).

\subsection{Barium sampling and sample processing}

A total of 13 stations were sampled for particulate barium from the surface to $2000 \mathrm{~m}$ (30 depths in total) in the ALG (station nos. 1, 2, 3, 10, Fast, 9 and 4), TYR (station nos. 5, Tyrr and 6) and ION (station nos. 8, 7 and Ion) basins (Table 1). Three of these stations were sampled twice on different days (long-duration stations Fast, Tyrr and Ion); however, due to technical problems, no particulate barium data are available for the second visit to Ion station. A total of $3 \mathrm{~d}$ separate both visits to Fast station and $2 \mathrm{~d}$ separate both visits to Tyrr station.

For particulate barium, 4-6L of seawater sampled using Niskin bottles was filtered onto $47 \mathrm{~mm}$ polycarbonate membranes $(0.4 \mu \mathrm{m}$ porosity) under slight overpressure sup- 


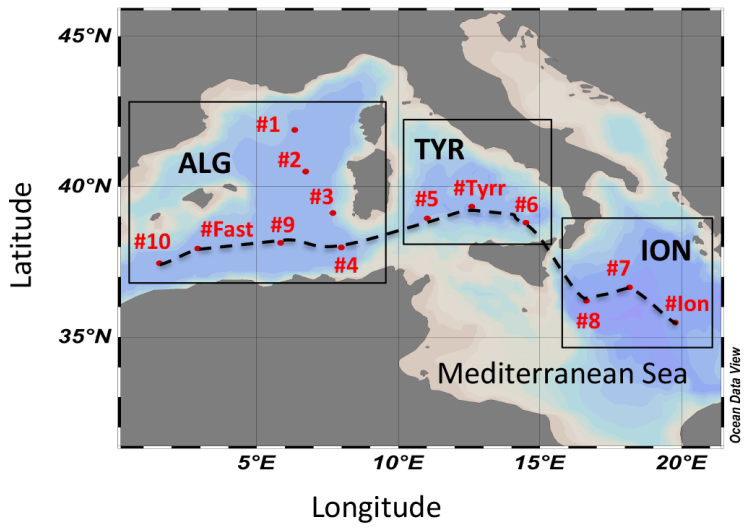

(a)

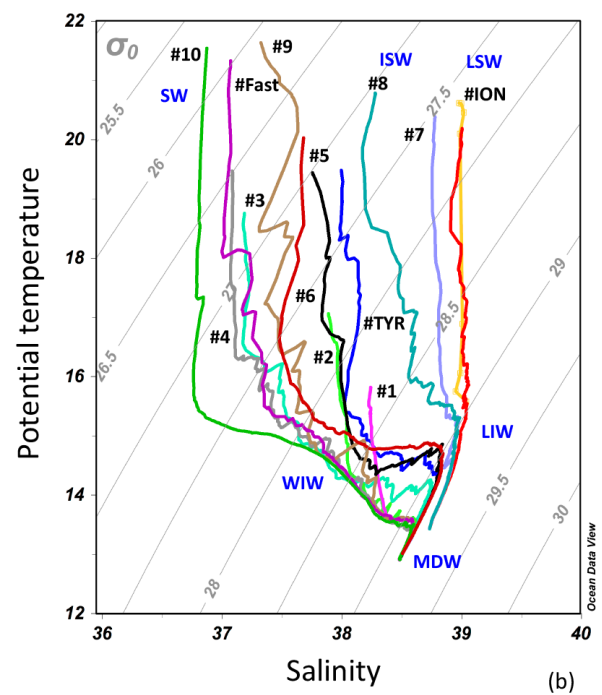

(b)

Figure 1. (a) Map of the study area showing the three sub-basins (ALG, TYRR and ION) and the stations' locations. The dashed line represents the zonal transect reported in Fig. 2. (b) Potential temperature-salinity diagram with isopynals $\left(\mathrm{kg} \mathrm{m}^{-3}\right)$ for PEACETIME profiles. The figure was produced using Ocean Data View (Schlitzer, 2002).

plied by filtered air. Filters were rinsed with a few millilitres of Milli-Q water to remove sea salt, dried $\left(50^{\circ} \mathrm{C}\right)$ and stored in Petri dishes for later analysis. In the laboratory, we performed a total digestion of filters using a concentrated tri-acid $\left(0.5 \mathrm{~mL} \mathrm{HF} / 1.5 \mathrm{~mL} \mathrm{HNO}_{3} / \mathrm{HCl} 1 \mathrm{~mL}\right.$; all Optima grade) mixture in closed Teflon beakers overnight at $95^{\circ} \mathrm{C}$ in a clean pressurized room. After evaporation close to dryness, samples were re-dissolved into $10 \mathrm{~mL}$ of $2 \% \mathrm{HNO}_{3}$. Subsequently, samples were analysed for $\mathrm{Ba}$ and other elements of interest (i.e. $\mathrm{Al}, \mathrm{Na}, \mathrm{Sr}$ and $\mathrm{Ca}$ ) using high-resolution inductively coupled plasma-mass spectrometry (HR-ICP-MS; Element XR, Thermo Scientific). Based on analyses of external certified reference standards, accuracy and reproducibility were both within $\pm 5 \%$. More details on sample processing and analysis are given in Cardinal et al. (2001) and Jacquet et al. (2015). The presence of sea salt was checked by analysing $\mathrm{Na}$, and the sea-salt particulate $\mathrm{Ba}$ contribution was found to be negligible $(<0.1 \%$ of total $\mathrm{Ba})$. Particulate biogenic barium in excess (hereafter referred to as $\mathrm{Ba}_{\mathrm{xs}}$ ) was calculated as the difference between total $\mathrm{Ba}$ and lithogenic $\mathrm{Ba}$. The lithogenic $\mathrm{Ba}$ concentration was determined using the $\mathrm{Al}$ concentration and the upper-continentalcrust (UCC) Ba : Al molar ratio (Dymond et al., 1992; Taylor and Mc Lennan, 1985). The standard uncertainty (Ellison et al., 2000) on $\mathrm{Ba}_{\mathrm{xs}}$ concentration ranges from $5.0 \%$ to $5.5 \%$. The term "in excess" is used to indicate that concentrations are larger than the $\mathrm{Ba}_{\mathrm{xs}}$ background ( $\mathrm{Ba} \mathrm{Bkg}$ ). The background (or residual value) is considered as "preformed" $\mathrm{Ba}_{\mathrm{xs}}$ at zero oxygen consumption left over after the transfer and partial dissolution of $\mathrm{Ba}_{\mathrm{xs}}$ produced during the degradation of previous particle export events. This background $\mathrm{Ba}_{\mathrm{xs}}$ value likely depends on the saturation state of the water with respect to barite $\left(\mathrm{BaSO}_{4}\right.$, the main phase of partic- ulate biogenic barium). Saturation indexes were reported in Jacquet et al. (2016) over a high-resolution and quasi-zonal Mediterranean transect (M84/3 cruise; Tanhua et al., 2013a, b). They revealed that the water column throughout the study area is largely undersaturated, with a saturation state ranging from 0.2 to 0.6 . A background $\mathrm{Ba}_{\mathrm{xs}}$ value of $130 \mathrm{pM}$ was recently reported in Jacquet et al. (2021). It is close to the average $\mathrm{Ba}_{\mathrm{xs}}$ content observed at greater depth $(>1000 \mathrm{~m})$ in the present study (see below).

\subsection{Prokaryotic heterotrophic production}

Prokaryotic heterotrophic production (PHP) estimation was measured by the L- $\left(4,5-{ }^{3} \mathrm{H}\right)$ Leucine $\left({ }^{3} \mathrm{H}\right.$-Leu, specific activity $109 \mathrm{Ci} \mathrm{mmol}^{-1}$, PerkinElmer $\left.{ }^{\circledR}\right)$ incorporation technique (Kirchman, 1993). Details of the protocols can be found in Van Wambeke et al. (2020). Briefly, in epipelagic layers (0$200 \mathrm{~m}), 1.5 \mathrm{~mL}$ seawater samples were incubated at $20 \mathrm{nM}$ ${ }^{3} \mathrm{H}$-Leu final concentration using the microcentrifuge technique (Smith and Azam, 1992). For the mesopelagic layers, $20 \mathrm{~mL}$ (200-800 m depth) and $40 \mathrm{~mL}$ (below $800 \mathrm{~m}$ depth) seawater samples were incubated using $20 \mathrm{nM}$ and $10 \mathrm{nM}$ ${ }^{3} \mathrm{H}$-Leu final concentration respectively with the filtration technique (Tamburini et al., 2002). Samples were incubated at in situ temperature. To calculate PHP, we used the empirical conversion factor of $1.5 \mathrm{ng} \mathrm{C}$ per picomole of incorporated leucine assuming that isotopic dilution was negligible under saturating concentrations of leucine as checked occasionally from concentration kinetics (Van Wambeke et al., 2020). 
Table 1. Depth-weighted average (DWA) concentrations of $\mathrm{Ba}_{\mathrm{xs}}(\mathrm{pM})$ and the remineralization rate $\left(\mathrm{MR} \mathrm{mgCm}^{-2} \mathrm{~d}^{-1}\right)$ for the upper (100- $500 \mathrm{~m}$ depth) and entire (100-1000 $\mathrm{m}$ depth) mesopelagic layer.

\begin{tabular}{|c|c|c|c|c|c|}
\hline Basin & Station no. & $\begin{array}{l}\text { Mesopelagic } \\
\text { layer }\end{array}$ & $\begin{array}{r}\text { DWA [pM] } \\
\mathrm{Ba}_{\mathrm{xs}}\end{array}$ & $\begin{array}{r}\text { MR } \\
{\left[\mathrm{mg} \mathrm{C} \mathrm{m}^{-2} \mathrm{~d}^{-1}\right]}\end{array}$ & $\begin{array}{r}\text { MR SE* } \\
{[\%]}\end{array}$ \\
\hline \multirow[t]{16}{*}{ Algero-Provençal } & 1 & upper & 542 & 94 & 20 \\
\hline & 1 & Entire & 374 & 117 & 27 \\
\hline & 2 & Upper & 717 & 131 & 26 \\
\hline & 2 & Entire & 645 & 245 & 28 \\
\hline & 3 & Upper & 402 & 58 & 13 \\
\hline & 3 & Entire & 353 & 104 & 25 \\
\hline & 4 & Upper & 243 & 25 & 8 \\
\hline & 4 & Entire & 281 & 71 & 20 \\
\hline & 9 & Upper & 981 & 91 & 19 \\
\hline & 9 & Entire & 979 & 306 & 23 \\
\hline & Fast1 & Upper & 638 & 105 & 21 \\
\hline & Fast1 & Entire & 527 & 183 & 38 \\
\hline & Fast3 & Upper & 596 & 99 & 20 \\
\hline & Fast3 & Entire & 381 & 117 & 27 \\
\hline & 10 & Upper & 418 & 60 & 13 \\
\hline & 10 & Entire & 410 & 129 & 29 \\
\hline \multirow[t]{8}{*}{ Tyrrhenian } & 5 & Upper & 283 & 32 & 9 \\
\hline & 5 & Entire & 226 & 45 & 17 \\
\hline & Tyrr2 & Upper & 284 & 32 & 9 \\
\hline & Tyrr2 & Entire & 200 & 32 & 15 \\
\hline & Tyrr4 & Upper & 542 & 84 & 17 \\
\hline & Tyrr4 & Entire & 380 & 114 & 26 \\
\hline & 6 & Upper & 404 & 58 & 13 \\
\hline & 6 & Entire & 313 & 85 & 22 \\
\hline \multirow[t]{6}{*}{ Ionian } & 7 & Upper & 769 & 139 & 28 \\
\hline & 7 & Entire & 485 & 167 & 36 \\
\hline & Ion & Upper & 456 & 58 & 13 \\
\hline & Ion & Entire & 315 & 52 & 13 \\
\hline & 8 & Upper & 363 & 41 & 10 \\
\hline & 8 & Entire & 273 & 62 & 18 \\
\hline
\end{tabular}

* SE: standard error.

\subsection{POC remineralization rates}

We recently reported on the validity of the Dehairs's transfer function (Dehairs et al., 1997) in the Mediterranean Basin to estimate mesopelagic POC remineralization (Jacquet et al., 2021). We applied a similar approach to estimate the remineralization rate (MR):

$\mathrm{MR}=\left[\left(\mathrm{Ba}_{\mathrm{xs}}-\mathrm{Ba} \mathrm{Bkg}\right) / 17450\right] \cdot Z \cdot \mathrm{RR}$,

where $\mathrm{Ba}_{\mathrm{xs}}$ is the depth-weighted average $\mathrm{Ba}_{\mathrm{xs}}$ concentration (DWA; $\mathrm{pM}$ ), i.e. the $\mathrm{Ba}_{\mathrm{xs}}$ inventory divided by the depth layer considered $(Z)$, and $\mathrm{RR}$ is the Redfield $\mathrm{C} / \mathrm{O}_{2}$ molar ratio (127/175; Broecker et al., 1985). As reported above, a Ba Bkg concentration of $130 \mathrm{pM}$ was used. MRs were then integrated over the 100-500 m (upper mesopelagic zone) and 100-1000 m (entire mesopelagic zone) depth layers.

\section{Results}

Particulate biogenic $\mathrm{Ba}_{\mathrm{xs}}$, biogenic $\mathrm{Ba}$ fraction (\%), and particulate $\mathrm{Al}, \mathrm{Sr}$ and $\mathrm{Ca}$ concentrations are reported in Fig. 2 in the upper $2000 \mathrm{~m}$ of the water column along a zonal transect crossing the three main sub-basins. PHP rates are also reported in Fig. 2 in the upper $500 \mathrm{~m}$ along the same transect.

$\mathrm{Ba}_{\mathrm{xs}}$ displayed a similar water column distribution to that reported in various sectors of the global Ocean: relatively low surface concentrations; a maximum in the mesopelagic layer (100-1000 m); and a decrease in concentrations back to a background level at deeper depths, usually $1000 \mathrm{~m}$ (Fig. 3). At station nos. 9, Tyrr, 8 and Ion, $\mathrm{Ba}_{\mathrm{xs}}$ concentrations in the upper $100 \mathrm{~m}$ were quite high $(>5000 \mathrm{pM})$, with values reaching up to $11700 \mathrm{pM}$ at $80 \mathrm{~m}$ depth at Tyrr station (Fig. 2a). Such high $\mathrm{Ba}_{\mathrm{xs}}$ concentrations in the upper layers 

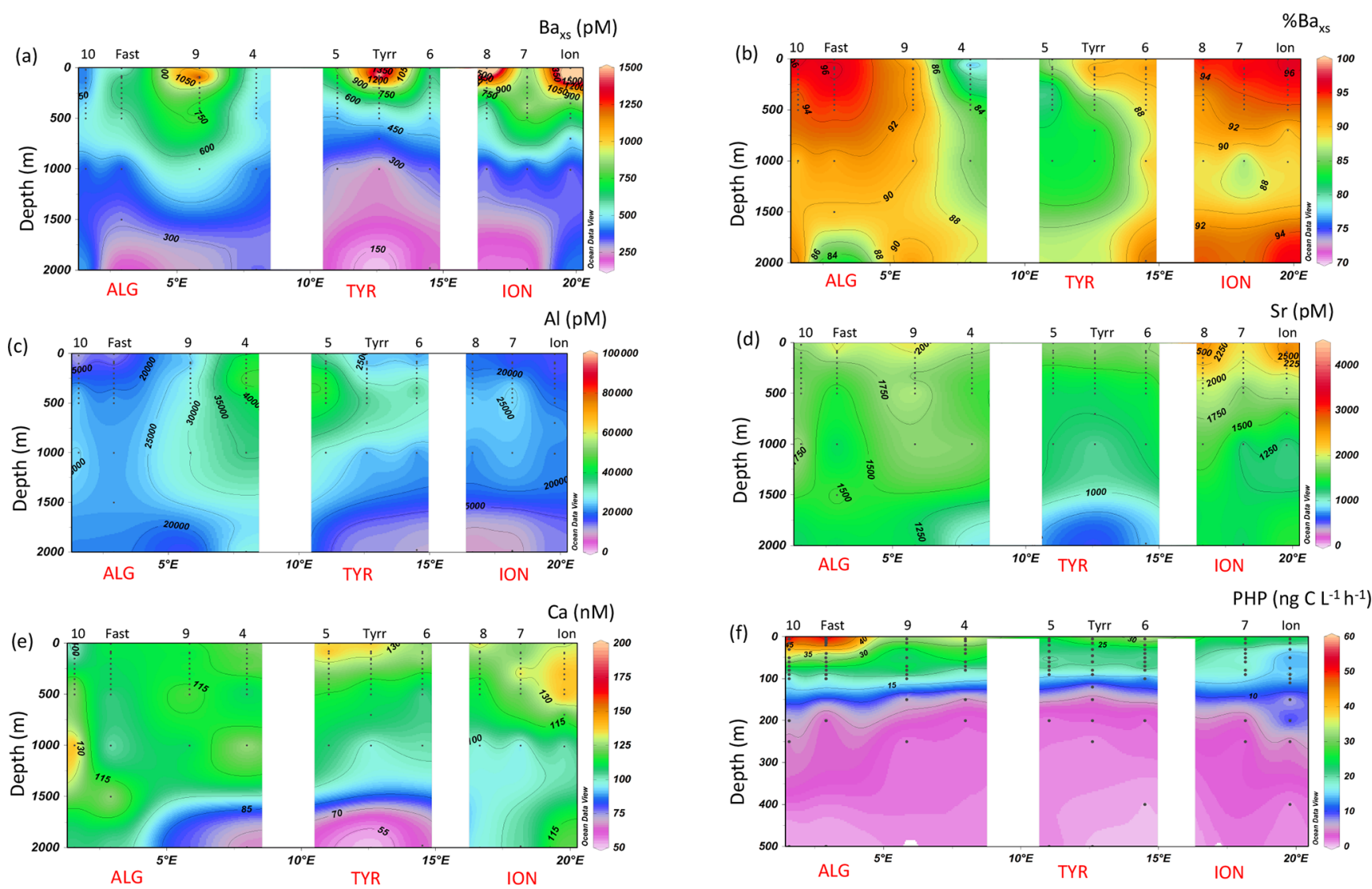

Figure 2. Sections of (a) particulate biogenic $\mathrm{Ba}\left(\mathrm{Ba}_{\mathrm{xs}}, \mathrm{pM}\right)$, (c) $\mathrm{Al}(\mathrm{pM}),(\mathbf{d}) \mathrm{Sr}(\mathrm{pM})$ and (e) $\mathrm{Ca}(\mathrm{nM})$ concentrations, and (b) the percentage $(\%)$ of biogenic $\mathrm{Ba}\left(\mathrm{Ba}_{\mathrm{xs}}\right)$ in the upper $2000 \mathrm{~m}$ of the water column. (f) Section of PHP $\left(\mathrm{ngCL}^{-1} \mathrm{~h}^{-1}\right)$ in the upper $500 \mathrm{~m}$ of the water column. The figure was produced using Ocean Data View (Schlitzer, 2002).

are quite unusual, although similar values (up to $9000 \mathrm{pM}$ ) were occasionally observed in earlier Southern Ocean studies (Dehairs et al., 1991, 1997; Jacquet et al., 2007b, 2008a, b). The high $\mathrm{Ba}_{\mathrm{xs}}$ values at Tyrr and Ion stations were associated with higher $\mathrm{Sr}$ (up to $4267 \mathrm{pM}$ at $100 \mathrm{~m}$ at Ion station) and $\mathrm{Ca}(>130 \mathrm{nM})$ concentrations (Fig. 2d, e). Throughout the water column, $\mathrm{Sr}$ and $\mathrm{Ca}$ concentrations ranged from to 448 to $6938 \mathrm{pM}$ and from 30 to $488 \mathrm{nM}$ respectively. $\mathrm{Sr} / \mathrm{Ca}$ molar ratios ranged from 7 to $45 \mathrm{mmol} \mathrm{mol}^{-1}$, which is within the range of ratios reported for organic material (Martin and Knauer, 1976). The upper mesopelagic layer (100-500 m) showed the characteristic Ba excess (maximum), as illustrated in Fig. 3a. The lithogenic impact on the $\mathrm{Ba}_{\mathrm{xs}}$ signal was relatively low $(<20 \%)$ except at station nos. 4,5 and Tyrr where it reached up to $30 \%$ at some depths in the water column (Figs. $2 \mathrm{~b}, 3 \mathrm{~b}$ ). High $\mathrm{Ba}_{\mathrm{xs}}$ concentrations at stations in the ALG Basin and at station no. 7 in the ION Basin extended deeper than at stations in the TYR Basin (Fig. 2a). At Ion station, the $\mathrm{Ba}_{\mathrm{xs}}$ maximum coincided with higher $\mathrm{Ca}$ (up to $186 \mathrm{nM}$ ) concentrations in the upper mesopelagic layer (Fig. 2e). However, the $\mathrm{Ba}_{\mathrm{xs}}$ maximum also extended deeper. This is especially salient at stations in the ALG Basin. At the other stations, $\mathrm{Ba}_{\mathrm{xs}}$ concentrations below $500 \mathrm{~m}$ decreased to reach the background value of around $130 \mathrm{pM}$. Among stations sampled twice for barium during the cruise, Fast station (ALG Basin) presented similar $\mathrm{Ba}_{\mathrm{xs}}$ profiles except between 400 and $1000 \mathrm{~m}$ depth where lower concentrations were measured during the second visit (3d later; Fig. 3a). The $\mathrm{Ba}_{\mathrm{xs}}$ signal was mostly biogenic and rather stable over the whole water column at this station. This was also the case at Ion station. In contrast, at Tyrr station, differences between $\mathrm{Ba}_{\mathrm{xs}}$ profiles mainly occurred in the surface layer and upper mesopelagic layer, with relatively higher $\mathrm{Ba}_{\mathrm{xs}}$ peaks during the second visit ( $2 \mathrm{~d}$ later; Fig. $3 \mathrm{~b}$ ). The biogenic Ba fraction was also more variable throughout the water column at Tyrr station.

PHP rates decreased from west to east in surface waters (Fig. 2f). At Fast station, PHP rates decreased from $49 \mathrm{ngCL}^{-1} \mathrm{~h}^{-1}$ in surface waters to values between 7 and $11 \mathrm{ng} \mathrm{CL}^{-1} \mathrm{~h}^{-1}$ at $100 \mathrm{~m}$ depth and below $6 \mathrm{ngCL}^{-1} \mathrm{~h}^{-1}$ below $200 \mathrm{~m}$ depth (Fig. 3d). The same trends were found at Tyrr and Ion stations with values in surface waters of around 36 and $25 \mathrm{ng} \mathrm{CL}^{-1} \mathrm{~h}^{-1}$ respectively (Fig. 3e, f). 


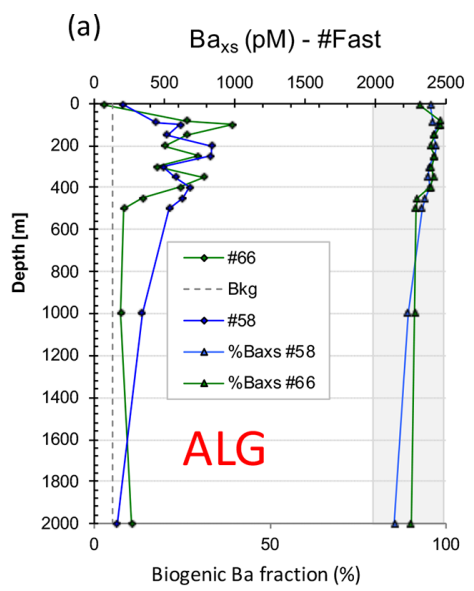

(d)

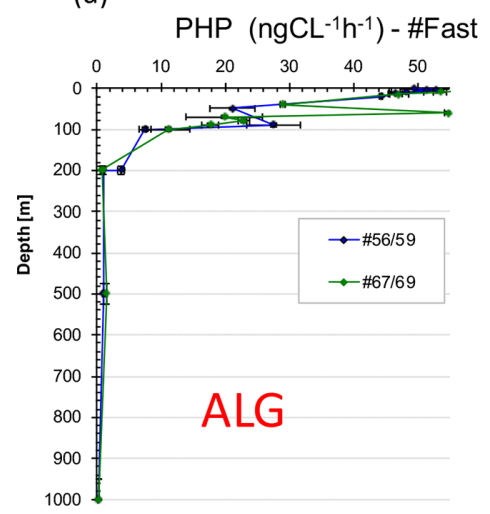

(b)

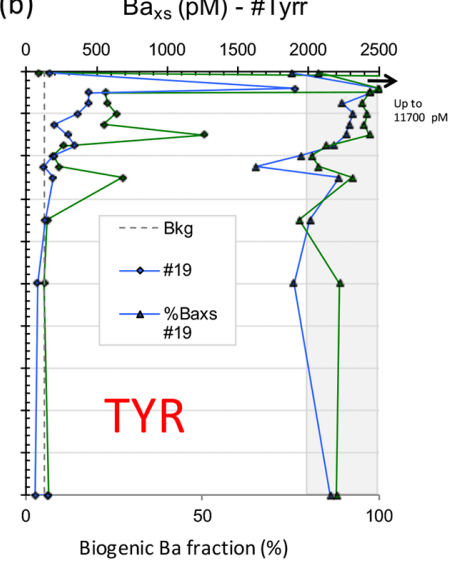

(e)

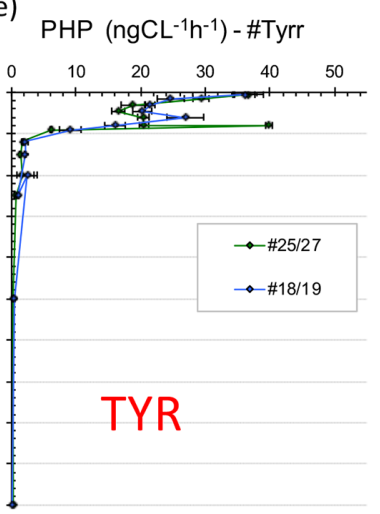

(c) $\quad \mathrm{Ba}_{\mathrm{xs}}(\mathrm{pM})-\#$ lon

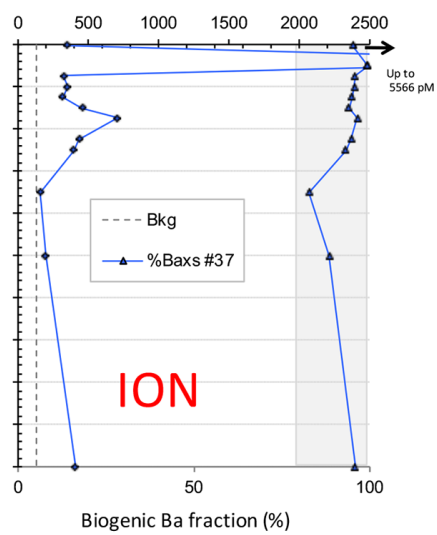

(f) PHP (ngCL-1 $\left.\mathrm{h}^{-1}\right)$ - \#lon

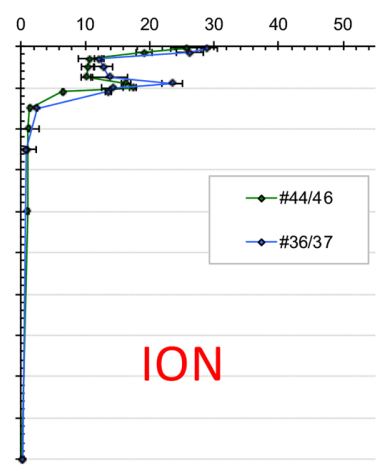

Figure 3. (a-c) $\mathrm{Ba}_{\mathrm{xs}}(\mathrm{pM})$ and (d-f) PHP $\left(\mathrm{ngCL}^{-1} \mathrm{~h}^{-1}\right)$ profiles in the upper 2000 and $1000 \mathrm{~m}$ of the water column respectively at longduration stations, Fast, Tyrr and Ion. (a-c) The dashed grey line represents the $\mathrm{Ba}_{\mathrm{xs}}$ background (Bkg), and the grey area represents the fraction for which $\mathrm{Ba}_{\mathrm{xs}}$ is mostly biogenic.

Depth-weighted average (DWA) concentrations of $\mathrm{Ba}_{\mathrm{xs}}$ are reported in Table 1 and Fig. 5 for the upper $(100-500 \mathrm{~m})$ and entire (100-1000 m) mesopelagic layer. As the base of the mixed layer was shallower than $100 \mathrm{~m}$, this depth is taken as the upper boundary of the mesopelagic domain. DWA values ranged from 221 to $979 \mathrm{pM}$. On average, stations located in the ALG Basin presented higher DWA values than in the TYR and ION basins. DWA $\mathrm{Ba}_{\mathrm{xs}}$ values remained rather stable over the $3 \mathrm{~d}$ period at Fast station between 100 and $500 \mathrm{~m}$ depth, but decreased in deeper layers (Fig. 5). As a consequence, the DWA changed from 527 to $381 \mathrm{pM}$ for the entire 100-1000 depth layer. In contrast, at Tyrr station, DWA $\mathrm{Ba}_{\mathrm{xs}}$ values for the $100-500 \mathrm{~m}$ and $100-1000 \mathrm{~m}$ depth layers increased over the $2 \mathrm{~d}$ period (from 284 to $542 \mathrm{pM}$ and from 200 to $380 \mathrm{pM}$ respectively). On average DWA $\mathrm{Ba}_{\mathrm{xs}}$ reached $577 \pm 286,378 \pm 123$ and $529 \pm 213 \mathrm{pM}(100-500 \mathrm{~m})$, and $527 \pm 288,280 \pm 82$ and $358 \pm 112 \mathrm{pM}(100-1000 \mathrm{~m})$ in the ALG, TYR and ION basins respectively.

\section{Discussion}

\section{1 $B a_{x s}$ distributions across the sub-basins}

The very high $\mathrm{Ba}_{\mathrm{xs}}$ concentrations reported in the surface layer at station nos. 9, Tyrr, 8 and Ion were associated with local $\mathrm{Sr}$ and $\mathrm{Ca}$ maxima, likely linked to potentially ballasted phytoplankton-derived material. Similar observations have previously been reported in the Southern Ocean, revealing that particulate $\mathrm{Ba}_{\mathrm{xs}}$ is incorporated into or adsorbed onto biogenic material in the surface water, with barite being a minor component (Dehairs et al., 1991, 1997; Jacquet et al., 2007a, 2008a, b). In deeper layers, $\mathrm{Ba}_{\mathrm{xs}}$ presented the characteristic maximum reflecting mesopelagic remineralization processes. Mesopelagic $\mathrm{Ba}_{\mathrm{xs}}$ distributions presented here were similar to those reported in Jacquet et al. (2021) and Sternberg et al. (2008) in the northwestern Mediterranean Sea (the ANTARES and DYFAMED observatory sites respectively). The $\mathrm{Ba}_{\mathrm{xs}}$ maximum extended down to $1000 \mathrm{~m}$ depth in the ALG Basin, whereas it was mostly located in the upper $500 \mathrm{~m}$ in the TYR Basin. The lithogenic impact on the $\mathrm{Ba}_{\mathrm{xS}}$ signal was relatively very low $(<5 \%)$, except at station 
nos. 4, 5 and Tyrr where it was more variable and reached up to $30 \%$ at some depths (Fig. 2b, c). A large dust deposition event occurred over a large area including the southern Tyrrhenian Sea just before the beginning of the PEACETIME campaign. Particulate $\mathrm{Al}$ concentrations and the estimated lithogenic $\mathrm{Ba}$ fraction were sampled at these stations 5-12d after the event and reflected the impact of this dust event at depth. These conclusions are further supported by results reported in Bressac et al. (2021), showing that Saharan dust depositions strongly impacted station nos. 4, 5, Tyrr and 6, where a significant fraction of dust particles was transferred to mesopelagic depths.

\subsection{Mesopelagic $B \mathrm{a}_{\mathrm{xs}}$ and prokaryotic heterotrophic production}

Previous studies have highlighted the relationship between the mesopelagic $\mathrm{Ba}_{\mathrm{xs}}$ and the vertical distribution of prokaryotic heterotrophic production (PHP), reflecting the temporal progression of the POC remineralization processes. In mesopelagic layers, the $\mathrm{Ba}_{\mathrm{xS}}$ content is smaller when most of the PHP occurs in the upper mixed layer (indicating an efficient, close to complete remineralization within the surface), compared with situations where a significant part of the PHP is located deeper in the water column (reflecting significant deep prokaryotic activity and POC export). Figure 3 shows the PHP profiles at the Fast, Tyrr and Ion long-duration stations (see also Van Wambeke et al., 2020, for more details on PHP). Figure 4 shows the ratio of integrated surface $(100 \mathrm{~m})$ to integrated upper mesopelagic $(500 \mathrm{~m})$ PHP vs. DWA $\mathrm{Ba}_{\mathrm{xs}}$ values calculated over the 100-500 m depth interval. Results are compared to the data obtained in the Southern Ocean (Jacquet et al., 2008a, 2015) and recently in the northeast Atlantic and northwestern Mediterranean Sea (the PAP and ANTARES observatory sites respectively) (Jacquet et al., 2021). The blue line in Fig. 4 represents the trend obtained during KEOPS2 (Kerguelen Ocean and Plateau Study 2; Jacquet et al., 2015); it does not include the encircled data points referred to as "season advancement". Results during PEACETIME followed a similar trend to that found for KEOPS2, with higher DWA $B a_{x s}$ values in situations where a significant part of the column-integrated PHP is located deeper in the water column (high IntPHP100/IntPHP500 ratio, Fig. 4). Note that some data points, characterized by low DWA $\mathrm{Ba}_{\mathrm{xs}}$ values, did not follow the trend from KEOPS2 (station nos. 3, 5 and Tyrr2). During KEOPS2, the lowest DWA values were reported for stations located in a meander and reflecting different (earlier) stages of a bloom compared with the other stations (see "season advancement" in Fig. 4). Similarly, station nos. 5 and Tyrr2 reflected the temporal evolution of the establishment (or advanced stages) of mesopelagic remineralization processes in the TYR Basin compared with the other basins. Measurements carried out during the second visit to Tyrr station $2 \mathrm{~d}$ later corroborated this hypothesis, showing an increase in remineraliza- tion in the upper mesopelagic layer (DWA $\mathrm{Ba}_{\mathrm{xs}}$ increased from 284 to $542 \mathrm{pM}$ ). At the DYFAMED station, Sternberg et al. (2008) reported the seasonal evolution of $\mathrm{Ba}_{\mathrm{xs}}$ profiles on a monthly basis between February and June 2003. These authors showed the mesopelagic $\mathrm{Ba}_{\mathrm{xs}}$ build up (and barite stock increase) following the spring phytoplankton bloom development, enhanced POC fluxes and subsequent remineralization. Overall, the DWA $\mathrm{Ba}_{\mathrm{xs}}$ values reported in the present study were higher than those reported by Sternberg et al. (2008) (maximum of $463 \mathrm{pM} ; 0-600 \mathrm{~m}$ ). The variability over the $2 \mathrm{~d}$ period at Tyrr station was of the same order of magnitude as the seasonal DWA $\mathrm{Ba}_{\mathrm{xs}}$ dynamics found at DYFAMED and similar to changes found over a few days to a week-long period in different sectors of the Southern Ocean (Cardinal et al., 2005; Jacquet et al., 2007a, 2015). The column-integrated PHP vs. DWA $\mathrm{Ba}_{\mathrm{xs}}$ ratio at Tyrr station confirms that the second visit experienced higher remineralization rates in the upper mesopelagic layer than during the first one (Table 1).

\subsection{Mesopelagic $\mathrm{C}$ remineralization}

POC remineralization rates (MRs) estimated from DWA $\mathrm{Ba}_{\mathrm{xs}}$ values using Eq. (1) are shown in Fig. 5 for the upper (100$500 \mathrm{~m})$ and entire $(100-1000 \mathrm{~m})$ mesopelagic layer along with primary productivity (Van Wambecke et al., 2021). The MRs ranged from $25 \pm 2$ to $306 \pm 70 \mathrm{mg} \mathrm{Cm}^{-2} \mathrm{~d}^{-1}$, and primary production ranged from 138 to $284 \mathrm{mg} \mathrm{Cm}^{-2} \mathrm{~d}^{-1}$. A large difference in MRs between the upper and the whole mesopelagic layers can be seen in the ALG Basin. This is more pronounced at station no. 9, which has MRs of $91 \mathrm{mg} \mathrm{C} \mathrm{m}^{-2} \mathrm{~d}^{-1}$ in the upper (100 to $500 \mathrm{~m}$ depth) layer and $306 \mathrm{mg} \mathrm{C} \mathrm{m}^{-2} \mathrm{~d}^{-1}$ in the entire mesopelagic layer (Fig. 5). These results show that significant remineralization occurred between 500 and $1000 \mathrm{~m}$ in the ALG Basin in contrast to the ION and TYR basins, where remineralization mainly occurred in the mesopelagic layer between 100 and $500 \mathrm{~m}$ depth. A similar conclusion was reached by Jullion et al. (2017) from dissolved $\mathrm{Ba}$ and parametric optimum multiparameter (POMP) derived POC remineralization rates along a zonal transect between the Lebanese coast and Gibraltar (from 156 to $348 \mathrm{mg} \mathrm{C} \mathrm{m}^{-2} \mathrm{~d}^{-1}$; M84/3 cruise, April 2011). Independent of any dust input considerations, Jullion et al. (2017) showed significant differences in the mesopelagic MRs between the western and eastern Mediterranean, indicating an additional organic carbon export pathway to depth. The western basin is indeed the site of deep-shelf and open-ocean convection, transferring organic matter to deeper layers (Durrieu de Madron et al., 2013; Stabholz et al., 2013). The larger MR fluxes found in the ALG Basin during PEACETIME are in line with an ecoregion with the recurrent injection of material by winter convection (the particle injection pump hypothesis; Boyd et al., 2019), sustaining higher rates of remineralization below $500 \mathrm{~m}$ depth. In contrast, in the TYR Basin, remineralization was mainly located in the upper mesopelagic layer. Stations in the TYR 


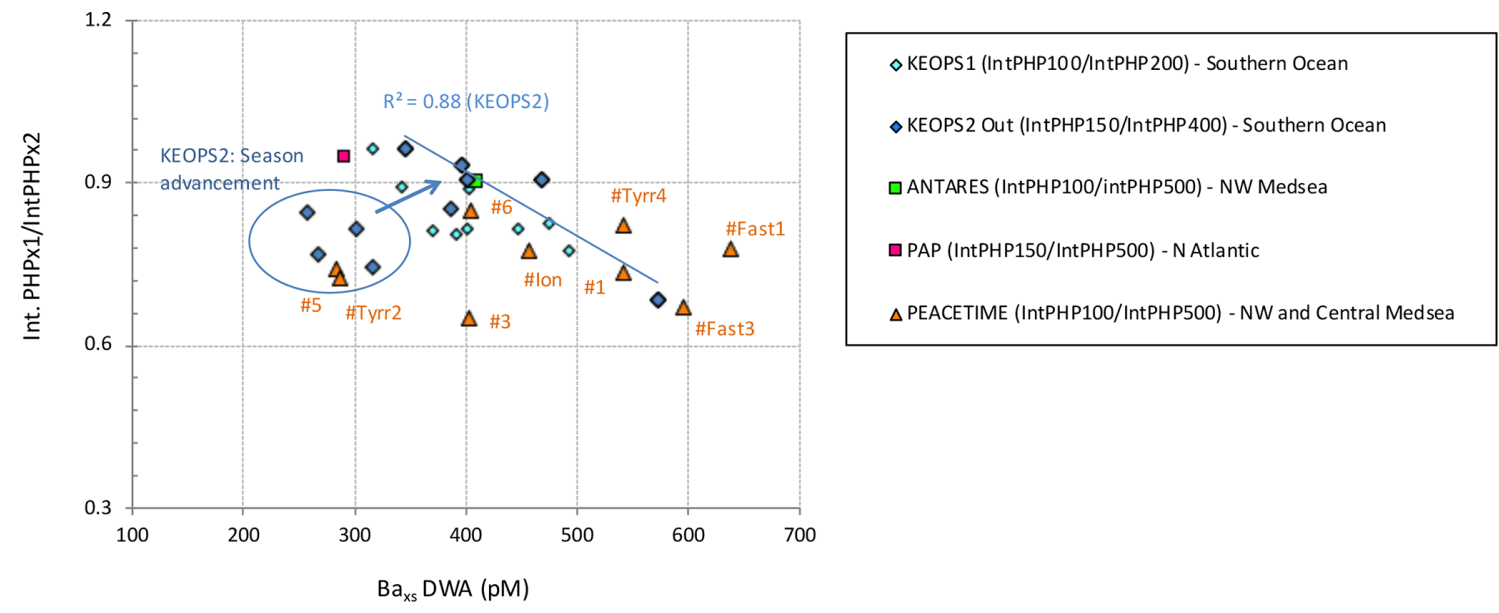

Figure 4. Ratio of surface layer integrated PHP (Int.PHPx1) to mesopelagic integrated PHP (IntPHPx2) vs. mesopelagic depth-weighted average (DWA) $\mathrm{Ba}_{\mathrm{xs}}(\mathrm{pM})$ during PEACETIME. The same data are reported for the KEOPS1 and KEOPS2 cruises (Southern Ocean; Jacquet et al., 2015) and at the PAP (northeastern Atlantic - "N Atlantic") and ANTARES/EMSO-LO (northwestern Mediterranean Sea "NW Medsea") observatory sites (Jacquet et al., 2021). The blue line $\left(R^{2}=0.88\right)$ represents the trend reported during KEOPS2 (Jacquet et al., 2005). The data points referred to as "season advancement" (encircled by the blue line) were excluded from the KEOPS 2 regression analysis shown here.

Basin received dust inputs a few days before our arrival at these locations; the particulate $\mathrm{Al}$ concentrations and estimated lithogenic Ba fraction reflected the impact of this event (Fig. 2; Bressac et al., 2021). At Tyrr station, the DAW Baxs vs. column-integrated PHP increase between the two visits indicated higher MRs. MRs were mainly localized in the upper $500 \mathrm{~m}$. Another atmospheric deposition event occurred on 5 June, a few hours after the first sampling at Fast station in the ALG Basin. However, Fast station does not present any evidence of an impact from particulate $\mathrm{Al}$ concentrations and estimated lithogenic $\mathrm{Ba}$ at mesopelagic depths. In contrast to conditions in the surface mixed layer, the generation of an observable signal from mesopelagic remineralization and subsequent $\mathrm{Ba}_{\mathrm{xs}}$ formation from a single dust event would require more time than the time span between atmospheric deposition and sampling at Fast station (in contrast to Tyrr station where the dust event occurred 5-12 d before sampling). In the ION Basin, where stations did not reflect the impact of any deposition event and were not subject to potential deep convection, DWA $\mathrm{Ba}_{\mathrm{xs}}$ and MR fluxes were mostly restricted to the upper mesopelagic layer. Berline et al. (2021) report small-scale heterogeneity in particle abundances at ION stations, emphasizing the spatial decoupling between particle production and particle distribution and adding complexity to estimating the time lag between the production and export of particles and, thus, C transfer at depth (Stange et al., 2017; Henson et al., 2011). Further, no significant surface production events occurred in the ION Basin However, surface particles at station no. 8 seemed related to a past production event without significant vertical export by the time the station was sampled. As reported in Van Wambeke et al. (2020), primary production fluxes were slightly higher

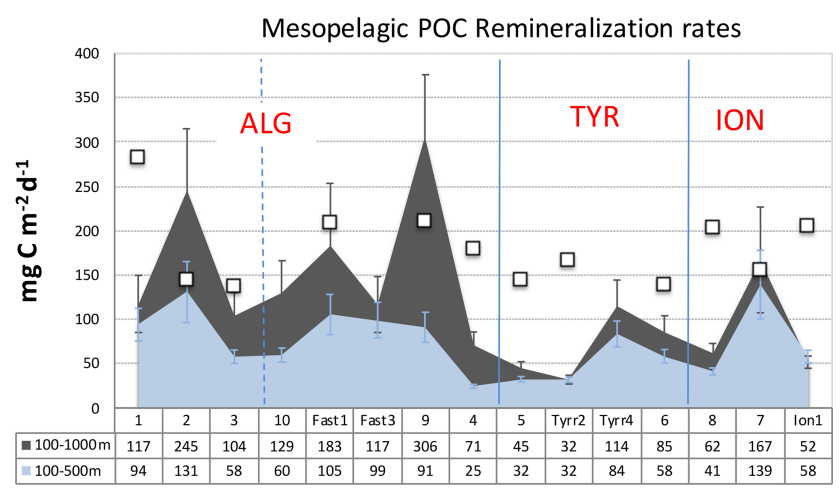

Figure 5. Integrated POC remineralization rates $\left(\mathrm{mg} \mathrm{Cm}^{-2} \mathrm{~d}^{-1}\right)$ in the upper (100-500 $\mathrm{m}$ depth) and entire (100-1000 $\mathrm{m}$ depth) mesopelagic layer in the ALG, TYR and ION basins. Open squares represent primary production $\left(\mathrm{mg} \mathrm{Cm}^{-2} \mathrm{~d}^{-1}\right.$; Van Wambeke et al., 2020).

in the ION Basin (from 158 to $208 \mathrm{mg} \mathrm{Cm}^{-2} \mathrm{~d}^{-1}$ ) than in the TYR Basin (from 142 to $170 \mathrm{mg} \mathrm{Cm}^{-2} \mathrm{~d}^{-1}$ ). Thus, DWA $\mathrm{Ba}_{\mathrm{xs}}$ values and MR fluxes reported in the ION Basin would generally reflect the earlier stage of export and remineralization processes. The same applies to Tyrr2 station (in contrast to Tyrr4 station) according to the DWA $\mathrm{Ba}_{\mathrm{xs}}$ vs. integratedPHP trend.

\section{Conclusions}

The present paper expands the data coverage of the $\mathrm{Ba}_{\mathrm{xs}}$ distribution in the ALG, TYR and ION basins (western and central Mediterranean Sea) in late spring 2017. Results high- 
light that mesopelagic remineralization processes are mainly located in the upper $500 \mathrm{~m}$ horizon in the TYR and ION basins, whereas they occur in the lower mesopelagic zone (down to $1000 \mathrm{~m}$ ) in the ALG Basin. We suggest that particle injection driven by the seasonal winter deep convection in the western basin would sustain the larger and deeper MRs that we observed in the ALG Basin. In both the TYR and ION basins, $\mathrm{Ba}_{\mathrm{xs}}$ indicated lower (intensity) and upper mesopelagic-layer-restricted remineralization processes that could be the results of a previous dust deposition event (in particular at Tyrr station) or the patchiness of time lags between production and export of particles.

Data availability. The biogeochemical dataset collected during the PEACETIME cruise, SEANOE, is available from https://www. seanoe.org/data/00645/75747/, last access: 7 April 2021 (Guieu et al., 2020).

Author contributions. SJ wrote the paper with contributions from all co-authors. SJ and AD managed the barium analyses, and CT, MG, SG and FVV managed the PHP analyses. MG, SG and NB performed Ba sampling during the cruise.

Competing interests. The authors declare that they have no known competing financial interests or personal relationships that could have appeared to influence the work reported in this paper.

Special issue statement. This article is part of the special issue "Atmospheric deposition in the low-nutrient-low-chlorophyll (LNLC) ocean: effects on marine life today and in the future (ACP/BG interjournal SI)". It is not associated with a conference.

Disclaimer. Publisher's note: Copernicus Publications remains neutral with regard to jurisdictional claims in published maps and institutional affiliations.

Acknowledgements. This study is a contribution to the PEACETIME project (http://peacetime-project.org, last access: 7 April 2021), a joint initiative of the MERMEX and ChArMEx components. PEACETIME was endorsed as a process study by GEOTRACES. It is also a contribution to SOLAS and IMBER. We thank the captain and the crew of the RV Pourquoi Pas? for their professionalism and their work at sea. We warmly thank Cécile Guieu and Karine Deboeufs, who are coordinators of the PEACETIME programme and chief scientists of the campaign. This work is a contribution to the "AT - POMPE BIOLOGIQUE" of the Mediterranean Institute of Oceanography (MIO).

Financial support. The project leading to this publication received funding from CNRS-INSU, IFREMER, CEA, and Météo-France as part of the MISTRALS programme coordinated by INSU (https://doi.org/10.17600/17000300). The HR-ICP-MS instrument (Element XR, Thermo Scientific) was supported by the European Regional Development Fund (ERDF) in 2012.

Review statement. This paper was edited by Christine Klaas and reviewed by two anonymous referees.

\section{References}

Ayata, S.-D., Irisson, J.-O., Aubert, A., Berline, L., Dutay, J.-C., Mayot, N., Nieblas, A.-E., D’Ortenzio, F., Palmiéri, J., Reygondeau, G., Rossi, V., and Guieu, C.: Regionalisation of the Mediterranean basin, a MERMEX synthesis, Prog. Oceanogr., 163, 7-20, https://doi.org/10.1016/j.pocean.2017.09.016, 2018.

van Beek, P., Sternberg, E., Reyss, J.-L., Souhaut, M., Robin, E., and Jeandel, C.: ${ }^{228} \mathrm{Ra} /{ }^{226} \mathrm{Ra}$ and ${ }^{226} \mathrm{Ra} / \mathrm{Ba}$ ratios in the Western Mediterranean Sea: Barite formation and transport in the water column, Geochim. Cosmochim. Ac., 73, 4720-4737, https://doi.org/10.1016/j.gca.2009.05.063, 2009.

Berline, L., Doglioli, A. M., Petrenko, A., Barrillon, S., Espinasse, B., Le Moigne, F. A. C., Simon-Bot, F., Thyssen, M., and Carlotti, F.: Long distance particle transport to the central Ionian Sea, Biogeosciences Discuss. [preprint], https://doi.org/10.5194/bg2020-481, in review, 2021.

Bertram, M. and P. Cowen, J.: Morphological and compositional evidence for biotic precipitation of marine barite, J. Mar. Res., 55, 577-593, 1997.

Boyd, P., Claustre, H., Levy, M., Siegel, D., and Weber, T.: Multi-faceted particle pumps drive carbon sequestration in the ocean, Nature, 568, 327-335, https://doi.org/10.1038/s41586019-1098-2, 2019.

Bressac, M., Wagener, T., Leblond, N., Tovar-Sánchez, A., Ridame, C., Albani, S., Guasco, S., Dufour, A., Jacquet, S., Dulac, F., Desboeufs, K., and Guieu, C.: Subsurface iron accumulation and rapid aluminium removal in the Mediterranean following African dust deposition, Biogeosciences Discuss. [preprint], https://doi.org/10.5194/bg-2021-87, in review, 2021.

Broecker, W. S., Takahashi, T., and Takahashi, T.: Sources and flow patterns of deep-ocean waters as deduced from potential temperature, salinity, and initial phosphate concentration, J. Geophys. Res., 90, 6925-6939, https://doi.org/10.1029/JC090iC04p06925, 1985.

Buesseler, K. O. and Boyd, P. W.: Shedding light on processes that control particle export and flux attenuation in the twilight zone of the open ocean, Limnol. Oceanogr., 54, 1210-1232, https://doi.org/10.4319/lo.2009.54.4.1210, 2009.

Buesseler, K. O., Lamborg, C. H., Boyd, P. W., Lam, P. J., Trull, T. W., Bidigare, R. R., Bishop, J. K. B., Casciotti, K. L., Dehairs, F., Elskens, M., Honda, M., Karl, D. M., Siegel, D. A., Silver, M. W., Steinberg, D. K., Valdes, J., Van Mooy, B., and Wilson, S.: Revisiting Carbon Flux Through the Ocean's Twilight Zone, Science, 316, 567-570, https://doi.org/10.1126/science.1137959, 2007.

Cardinal, D., Dehairs, F., Cattaldo, T., and André, L.: Geochemistry of suspended particles in the Subantarctic and Polar Frontal zones south of Australia: Constraints on export 
and advection processes, J. Geophys. Res., 106, 31637-31656, https://doi.org/10.1029/2000JC000251, 2001.

Cardinal, D., Savoye, N., Trull, T. W., André, L., Kopczynska, E. E., and Dehairs, F.: Variations of carbon remineralisation in the Southern Ocean illustrated by the Baxs proxy, Deep-Sea Res. Pt. I, 52, 355-370, https://doi.org/10.1016/j.dsr.2004.10.002, 2005.

Dehairs, F., Chesselet, R., and Jedwab, J.: Discrete suspended particles of barite and the barium cycle in the open ocean, Earth Planet. Sc. Lett., 49, 528-550, https://doi.org/10.1016/0012821X(80)90094-1, 1980.

Dehairs, F., Lambert, C. E., Chesselet, R., and Risler, N.: The biological production of marine suspended barite and the barium cycle in the Western Mediterranean Sea, Biogeochemistry, 4, 119140, https://doi.org/10.1007/BF02180151, 1987.

Dehairs, F., Stroobants, N., and Goeyens, L.: Suspended barite as a tracer of biological activity in the Southern Ocean, Mar. Chem., 35, 399-410, https://doi.org/10.1016/S0304-4203(09)90032-9, 1991.

Dehairs, F., Shopova, D., Ober, S., Veth, C., and Goeyens, L.: Particulate barium stocks and oxygen consumption in the Southern Ocean mesopelagic water column during spring and early summer: relationship with export production, Deep-Sea Res. Pt. II, 44, 497-516, https://doi.org/10.1016/S0967-0645(96)00072$0,1997$.

Dehairs, F., Jacquet, S., Savoye, N., Van Mooy, B. A. S., Buesseler, K. O., Bishop, J. K. B., Lamborg, C. H., Elskens, M., Baeyens, W., Boyd, P. W., Casciotti, K. L., and Monnin, C.: Barium in twilight zone suspended matter as a potential proxy for particulate organic carbon remineralization: Results for the North Pacific, Deep-Sea Res. Pt. II, 55, 1673-1683, https://doi.org/10.1016/j.dsr2.2008.04.020, 2008.

Durrieu de Madron, X., Guieu, C., Sempéré, R., Conan, P., Cossa, D., D’Ortenzio, F., Estournel, C., Gazeau, F., Rabouille, C., Stemmann, L., Bonnet, S., Diaz, F., Koubbi, P., Radakovitch, O., Babin, M., Baklouti, M., Bancon-Montigny, C., Belviso, S., Bensoussan, N., Bonsang, B., Bouloubassi, I., Brunet, C., Cadiou, J.-F., Carlotti, F., Chami, M., Charmasson, S., Charrière, B., Dachs, J., Doxaran, D., Dutay, J.-C., Elbaz-Poulichet, F., Eléaume, M., Eyrolles, F., Fernandez, C., Fowler, S., Francour, P., Gaertner, J. C., Galzin, R., Gasparini, S., Ghiglione, J.-F., Gonzalez, J.-L., Goyet, C., Guidi, L., Guizien, K., Heimbürger, L.-E., Jacquet, S. H. M., Jeffrey, W. H., Joux, F., Le Hir, P., Leblanc, K., Lefèvre, D., Lejeusne, C., Lemé, R., Loÿe-Pilot, M.-D., Mallet, M., Méjanelle, L., Mélin, F., Mellon, C., Mérigot, B., Merle, P.-L., Migon, C., Miller, W. L., Mortier, L., Mostajir, B., Mousseau, L., Moutin, T., Para, J., Pérez, T., Petrenko, A., Poggiale, J.-C., Prieur, L., Pujo-Pay, M., Pulido-Villena, E., Raimbault, P., Rees, A. P., Ridame, C., Rontani, J.-F., Ruiz Pino, D., Sicre, M. A., Taillandier, V., Tamburini, C., Tanaka, T., Taupier-Letage, I., Tedetti, M., Testor, P., Thébault, H., Thouvenin, B., Touratier, F., Tronczynski, J., Ulses, C., Van Wambeke, F., Vantrepotte, V., Vaz, S., and Verney, R.: Marine ecosystems' responses to climatic and anthropogenic forcings in the Mediterranean, Prog. Oceanogr., 91, 97166, https://doi.org/10.1016/j.pocean.2011.02.003, 2011.

Dymond, J. R., Suess, E., and Lyle, M.: Barium in deep-sea sediment: a geochemical proxy for paleoproductivity, Paleoceanography, 7, 163-181, 1992.
Ellison, S. L. R.: Eurachem/CITAC Guide CG4, Quantifying Uncertainty in Analytical Measurement, 2nd edn., edited by: Ellison, S. L. R., Rosslein, M., and Williams, A., 120 pp., ISBN 0948926 155,2000

Ganeshram, R. S., François, R., Commeau, J., and BrownLeger, S. L.: An experimental investigation of barite formation in seawater, Geochim. Cosmochim. Ac., 67, 2599-2605, https://doi.org/10.1016/S0016-7037(03)00164-9, 2003.

Gazeau, F., Van Wambeke, F., Marañón, E., Pérez-Lorenzo, M., Alliouane, S., Stolpe, C., Blasco, T., Leblond, N., Zäncker, B., Engel, A., Marie, B., Dinasquet, J., and Guieu, C.: Impact of dust addition on the metabolism of Mediterranean plankton communities and carbon export under present and future conditions of $\mathrm{pH}$ and temperature, Biogeosciences, 18, 5423-5446, https://doi.org/10.5194/bg-18-5423-2021, 2021.

Guieu, C. and Desboeufs, K.: PEACETIME cruise, RV Pourquoi pas?, https://doi.org/10.17600/17000300, 2017.

Guieu, C., D’Ortenzio, F., Dulac, F., Taillandier, V., Doglioli, A., Petrenko, A., Barrillon, S., Mallet, M., Nabat, P., and Desboeufs, K.: Introduction: Process studies at the air-sea interface after atmospheric deposition in the Mediterranean Sea - objectives and strategy of the PEACETIME oceanographic campaign (May-June 2017), Biogeosciences, 17, 5563-5585, https://doi.org/10.5194/bg-17-5563-2020, 2020a.

Guieu, C., Desboeufs, K., Albani, S., Alliouane, S., Aumont, O., Barbieux, M., Barrillon, S., Baudoux, A.-C., Berline, L., Bhairy, N., Bigeard, E., Bloss, M., Bressac, M., Brito, J., Carlotti, F., de Liege, G., Dinasquet, J., Djaoudi, K., Doglioli, A., D’Ortenzio, F., Doussin, J.-F., Duforet, L., Dulac, F., Dutay, J.-C., Engel, A., Feliu-Brito, G., Ferre, H., Formenti, P., Fu, F., Garcia, D., Garel, M., Gazeau, F., Giorio, C., Gregori, G., Grisoni, J.-M., Guasco, S., Guittonneau, J., Haëntjens, N., Heimburger, L.-E., Helias, S., Jacquet, S., Laurent, B., Leblond, N., Lefevre, D., Mallet, M., Marañ̃ón, E., Nabat, P., Nicosia, A., Obernosterer, I., Pérez-Lorenzo, M., Petrenko, A., Pulido-Villena, E., Raimbault, P., Ridame, C., Riffault, V., Rougier, G., Rousselet, L., Roy-Barman, M., Saiz-Lopez, A., Schmechtig, C., Sellegri, K., Siour, G., Taillandier, V., Tamburini, C., Thyssen, M., TovarSanchez, A., Triquet, S., Uitz, J., Van Wambeke, F., Wagener, T. and Zaencker, B.: BIOGEOCHEMICAL dataset collected during the PEACETIME cruise, SEANOE [data set], available at: https://www.seanoe.org/data/00645/75747/ (last access: 29 October 2021), 2020b.

Hainbucher, D., Rubino, A., Cardin, V., Tanhua, T., Schroeder, K., and Bensi, M.: Hydrographic situation during cruise M84/3 and P414 (spring 2011) in the Mediterranean Sea, Ocean Sci., 10, 669-682, https://doi.org/10.5194/os-10-669-2014, 2014.

Henson, S. A., Sanders, R., Madsen, E., Morris, P. J., Le Moigne, F., and Quartly, G. D.: A reduced estimate of the strength of the ocean's biological carbon pump, Geophys. Res. Lett., 38, L04606, https://doi.org/10.1029/2011GL046735, 2011.

IPCC: 5th Assessment Report (AR5) Climate Change 2013, Working Group 1, January 2014.

Jacquet, S. H. M., Dehairs, F., Elskens, M., Savoye, N., and Cardinal, D.: Barium cycling along WOCE SR3 line in the Southern Ocean, Mar. Chem., 106, 33-45, https://doi.org/10.1016/j.marchem.2006.06.007, 2007a.

Jacquet, S. H. M., Henjes, J., Dehairs, F., Worobiec, A., Savoye, N., and Cardinal, D.: Particulate Ba-barite and acantharians 
in the Southern Ocean during the European Iron Fertilization Experiment (EIFEX), J. Geophys. Res., 112, G04006, https://doi.org/10.1029/2006JG000394, 2007b.

Jacquet, S. H. M., Savoye, N., Dehairs, F., Strass, V. H., and Cardinal, D.: Mesopelagic carbon remineralization during the European Iron Fertilization Experiment, Global Biogeochem. Cy., 22, GB1023, https://doi.org/10.1029/2006GB002902, 2008a.

Jacquet, S. H. M., Dehairs, F., Savoye, N., Obernosterer, I., Christaki, U., Monnin, C., and Cardinal, D.: Mesopelagic organic carbon remineralization in the Kerguelen Plateau region tracked by biogenic particulate Ba, Deep-Sea Res. Pt. II, 55, 868-879, https://doi.org/10.1016/j.dsr2.2007.12.038, 2008b.

Jacquet, S. H. M., Dehairs, F., Dumont, I., Becquevort, S., Cavagna, A.-J., and Cardinal, D.: Twilight zone organic carbon remineralization in the Polar Front Zone and Subantarctic Zone south of Tasmania, Deep-Sea Res. Pt. II, 58, 2222-2234, https://doi.org/10.1016/j.dsr2.2011.05.029, 2011.

Jacquet, S. H. M., Dehairs, F., Lefèvre, D., Cavagna, A. J., Planchon, F., Christaki, U., Monin, L., André, L., Closset, I., and Cardinal, D.: Early spring mesopelagic carbon remineralization and transfer efficiency in the naturally iron-fertilized Kerguelen area, Biogeosciences, 12, 1713-1731, https://doi.org/10.5194/bg-121713-2015, 2015.

Jacquet, S. H. M., Monnin, C., Riou, V., Jullion, L., and Tanhua, T.: A high resolution and quasi-zonal transect of dissolved $\mathrm{Ba}$ in the Mediterranean Sea, Mar. Chem., 178, 1-7, https://doi.org/10.1016/j.marchem.2015.12.001, 2016.

Jacquet, S. H. M., Lefèvre, D., Tamburini, C., Garel, M., Le Moigne, F. A. C., Bhairy, N., and Guasco, S.: On the bariumoxygen consumption relationship in the Mediterranean Sea: implications for mesopelagic marine snow remineralization, Biogeosciences, 18, 2205-2212, https://doi.org/10.5194/bg-182205-2021, 2021.

Jullion, L., Jacquet, S. H. M., and Tanhua, T.: Untangling biogeochemical processes from the impact of ocean circulation: First insight on the Mediterranean dissolved barium dynamics, Global Biogeochem. Cy., 31, 1256-1270, https://doi.org/10.1002/2016GB005489, 2017.

Kirchman, D. L.: Leucine incorporation as a measure of biomass production by heterotrophic bacteria, in: Handbooks of methods in aquatic microbial ecology, edited by: Kemp, P. F., Sherr, B. F., Sherr, E. B., and Cole, J. J., Lewis Publishers, Boca Raton, Ann Arbor, London, Tokyo, 509-512, 1993.

Kwon, E. Y., Primeau, F., and Sarmiento, J. L.: The impact of remineralization depth on the air-sea carbon balance, Nat. Geosci., 2, 630-635, https://doi.org/10.1038/ngeo612, 2009.

Lemaitre, N., Planquette, H., Planchon, F., Sarthou, G., Jacquet, S., García-Ibáñez, M. I., Gourain, A., Cheize, M., Monin, L., André, L., Laha, P., Terryn, H., and Dehairs, F.: Particulate barium tracing of significant mesopelagic carbon remineralisation in the North Atlantic, Biogeosciences, 15, 2289-2307, https://doi.org/10.5194/bg-15-2289-2018, 2018.

López-Sandoval, D. C., Fernández, A., and Marañón, E.: Dissolved and particulate primary production along a longitudinal gradient in the Mediterranean Sea, Biogeosciences, 8, 815-825, https://doi.org/10.5194/bg-8-815-2011, 2011.

Luna, G. M., Bianchelli, S., Decembrini, F., De Domenico, E., Danovaro, R., and Dell'Anno, A.: The dark portion of the Mediterranean Sea is a bioreactor of or- ganic matter cycling, Global Biogeochem. Cy., 26, GB2017, https://doi.org/10.1029/2011GB004168, 2012.

Malanotte-Rizzoli, P., Artale, V., Borzelli-Eusebi, G. L., Brenner, S., Crise, A., Gacic, M., Kress, N., Marullo, S., Ribera d'Alcalà, M., Sofianos, S., Tanhua, T., Theocharis, A., Alvarez, M., Ashkenazy, Y., Bergamasco, A., Cardin, V., Carniel, S., Civitarese, G., D’Ortenzio, F., Font, J., Garcia-Ladona, E., Garcia-Lafuente, J. M., Gogou, A., Gregoire, M., Hainbucher, D., Kontoyannis, H., Kovacevic, V., Kraskapoulou, E., Kroskos, G., Incarbona, A., Mazzocchi, M. G., Orlic, M., Ozsoy, E., Pascual, A., Poulain, P.-M., Roether, W., Rubino, A., Schroeder, K., Siokou-Frangou, J., Souvermezoglou, E., Sprovieri, M., Tintoré, J., and Triantafyllou, G.: Physical forcing and physical/biochemical variability of the Mediterranean Sea: a review of unresolved issues and directions for future research, Ocean Sci., 10, 281-322, https://doi.org/10.5194/os-10-281-2014, 2014.

Martin, J. H. and Knauer, G. A.: Elemental composition of plankton, Geochim. Cosmochim. Ac., 37, 1639-1653, 1973.

Martin, J. H., Knauer, G. A., Karl, D. M., and Broenkow, W. W.: VERTEX: carbon cycling in the northeast Pacific, Deep-Sea Res., 34, 267-285, https://doi.org/10.1016/01980149(87)90086-0, 1987.

Monnin, C. and Cividini, D.: The saturation state of the world's ocean with respect to $(\mathrm{Ba}, \mathrm{Sr}) \mathrm{SO} 4$ solid solutions, Geochim. Cosmochim. Ac., 70, 3290-3298, https://doi.org/10.1016/j.gca.2006.04.002, 2006.

Moutin, T. and Raimbault, P.: Primary production, carbon export and nutrients availability in western and eastern Mediterranean Sea in early summer 1996 (MINOS cruise), J. Marine Syst., 33-34, 273-288, https://doi.org/10.1016/S0924-7963(02)000623, 2002.

Pabortsava, K., Lampitt, R. S., Benson, J., Crowe, C., McLachlan, R., Le Moigne, F. A. C., Mark Moore, C., Pebody, C., Provost, P., Rees, A. P., Tilstone, G. H., and Woodward, E. M. S.: Carbon sequestration in the deep Atlantic enhanced by Saharan dust, Nat Geosci., 10, 189-194, https://doi.org/10.1038/ngeo2899, 2017.

Planchon, F., Cavagna, A.-J., Cardinal, D., André, L., and Dehairs, F.: Late summer particulate organic carbon export and twilight zone remineralisation in the Atlantic sector of the Southern Ocean, Biogeosciences, 10, 803-820, https://doi.org/10.5194/bg-10-803-2013, 2013.

Pujo-Pay, M., Conan, P., Oriol, L., Cornet-Barthaux, V., Falco, C., Ghiglione, J.-F., Goyet, C., Moutin, T., and Prieur, L.: Integrated survey of elemental stoichiometry $(\mathrm{C}, \mathrm{N}, \mathrm{P})$ from the western to eastern Mediterranean Sea, Biogeosciences, 8, 883899, https://doi.org/10.5194/bg-8-883-2011, 2011.

Reygondeau, G., Guieu, C., Benedetti, F., Irisson, J.-O., Ayata, S.D., Gasparini, S., and Koubbi, P.: Biogeochemical regions of the Mediterranean Sea: An objective multidimensional and multivariate environmental approach, Prog. Oceanogr., 151, 138-148, https://doi.org/10.1016/j.pocean.2016.11.001, 2017.

Sanchez-Vidal, A., Collier, R. W., Calafat, A., Fabres, J., and Canals, M.: Particulate barium fluxes on the continental margin: a study from the Alboran Sea (Western Mediterranean), Mar. Chem., 93, 105-117, https://doi.org/10.1016/j.marchem.2004.07.004, 2005.

Santinelli, C., Nannicini, L., and Seritti, A.: DOC dynamics in the meso and bathypelagic layers of the 
Mediterranean Sea, Deep-Sea Res. Pt. II, 57, 1446-1459, https://doi.org/10.1016/j.dsr2.2010.02.014, 2010.

Schlitzer, R.: Ocean Data View, GEO/ODV, available at: https://odv. awi.de/ (last access: 2 March 2021), 2002.

Simon, M. and Azam, F.: Protein content and protein synthesis rates of planktonic marine bacteria, Mar. Ecol. Prog. Ser., 51, 201213, 1989.

Stabholz, M., Durrieu de Madron, X., Canals, M., Khripounoff, A., Taupier-Letage, I., Testor, P., Heussner, S., Kerhervé, P., Delsaut, N., Houpert, L., Lastras, G., and Dennielou, B.: Impact of openocean convection on particle fluxes and sediment dynamics in the deep margin of the Gulf of Lions, Biogeosciences, 10, 10971116, https://doi.org/10.5194/bg-10-1097-2013, 2013.

Stange, P., Bach, L. T., Le Moigne, F. A. C., Taucher, J., Boxhammer, T., and Riebesell, U.: Quantifying the time lag between organic matter production and export in the surface ocean: Implications for estimates of export efficiency, Geophys. Res. Lett., 44, 268-276, https://doi.org/10.1002/2016GL070875, 2017.

Sternberg, E., Jeandel, C., Miquel, J.-C., Gasser, B., Souhaut, M., Arraes-Mescoff, R., and Francois, R.: Particulate barium fluxes and export production in the northwestern Mediterranean, Mar. Chem., 105, 281-295, https://doi.org/10.1016/j.marchem.2007.03.003, 2007.

Sternberg, E., Jeandel, C., Robin, E., and Souhaut, M.: Seasonal cycle of suspended barite in the mediterranean sea, Geochim. Cosmochim. Ac., 72, 4020-4034, https://doi.org/10.1016/j.gca.2008.05.043, 2008.

Stroobants, N., Dehairs, F., Goeyens, L., Vanderheijden, N., and Van Grieken, R.: Barite formation in the Southern Ocean water column, Mar. Chem., 35, 411-421, https://doi.org/10.1016/S0304-4203(09)90033-0, 1991.
Tamburini, C., Garcin, J., Ragot, M., and Bianchi, A.: Biopolymer hydrolysis and bacterial production under ambient hydrostatic pressure through a $2000 \mathrm{~m}$ water column in the NW Mediterranean, Deep-Sea Res. Pt. I, 49, 2109-2123, https://doi.org/10.1016/S0967-0645(02)00030-9, 2002.

Tamburini, C., Boutrif, M., Garel, M., Colwell, R. R., and Deming, J. W.: Prokaryotic responses to hydrostatic pressure in the ocean - a review, Environ. Microbiol., 15, 1262-1274, https://doi.org/10.1111/1462-2920.12084, 2013.

Tanhua, T., Hainbucher, D., Cardin, V., Álvarez, M., Civitarese, G., McNichol, A. P., and Key, R. M.: Repeat hydrography in the Mediterranean Sea, data from the Meteor cruise 84/3 in 2011, Earth Syst. Sci. Data, 5, 289-294, https://doi.org/10.5194/essd5-289-2013, 2013a.

Tanhua, T., Hainbucher, D., Schroeder, K., Cardin, V., Álvarez, M., and Civitarese, G.: The Mediterranean Sea system: a review and an introduction to the special issue, Ocean Sci., 9, 789-803, https://doi.org/10.5194/os-9-789-2013, 2013b.

Taylor, S. R. and McLennan, S. M.: The continental crust: its composition and evolution, Blackwell Scientific Publications, USA, 312 pp., 1985.

Van Wambeke, F., Taillandier, V., Deboeufs, K., Pulido-Villena, E., Dinasquet, J., Engel, A., Marañón, E., Ridame, C., and Guieu, C.: Influence of atmospheric deposition on biogeochemical cycles in an oligotrophic ocean system, Biogeosciences Discuss. [preprint], https://doi.org/10.5194/bg-2020-411, in review, 2020. 